\title{
Qarakhanids on the Edge of the Bukhara Oasis: Archaeobotany of Medieval Paykend
}

\author{
Basira Mir-Makhamad ${ }^{1,2}$ (D), Sirojidin MirZaAkHMEdov ${ }^{3}$, \\ HusNidDin RAHMONOV ${ }^{3}$, SÖREN STARK ${ }^{4}$, ANDREy OMEL'CHENKo ${ }^{5}$, AND \\ ROBERT N. SPENGLER III ${ }^{1}$ \\ ${ }^{1}$ Archaeology Department, Max Planck Institute for the Science of Human History, Jena, \\ Germany \\ ${ }^{2}$ Ancient Oriental Studies Department, Friedrich Schiller University, Jena, Germany \\ ${ }^{3}$ Institute of Archaeology, Uzbekistan Academy of Sciences, Tashkent, Samarkand, Uzbekistan \\ ${ }^{4}$ Institute for the Study of the Ancient World, New York University, New York City, NY, USA \\ ${ }^{5}$ State Hermitage Museum, St. Petersburg, Russia \\ *Corresponding author; e-mail: mirmakhamad@shh.mpg.de
}

\begin{abstract}
The urban center of Paykend was an exchange node just off the main corridor of the Silk Road in the Bukhara Oasis on the edge of the hyperarid Kyzyl-Kum Desert. The city was occupied from the end of 4 century B.C.E. to the mid-12 century C.E.; our study focuses on the Qarakhanid period (C.E. 999 - 1211), the last imperial phase of urban occupation at Paykend before its abandonment. In this study, we present the results of an analysis of archaeobotanical remains recovered from a multifunction rabat, which appears to have comprised a domicile, military structure, center of commerce, and/or a caravanserai, a roadside inn for travelers. We shed light on how people adapted a productive economy to the local ecological constraints. By adding these data to the limited Qarakhanid archaeobotany from across Central Asia, we provide the first glimpses into cultivation, commerce, and consumption at a Silk Road trading town along the King's Road, the central artery of ancient Eurasia.
\end{abstract}

Key Words: Paykend, Qarakhanids, agriculture, Silk Road, arboriculture, millet, rice.

\section{Introduction}

The archaeology and history of the Silk Road have recently received considerable attention, emphasizing the influence of the trade routes in shaping cultures across Eurasia (Frankopan 2015; Spengler 2019a; Whitfield 2019). The lasting effects of the Silk Road are visible in the food we eat (Spengler 2019b), the genes of humans across Eurasia (Damgaard et al. 2018), and the languages many of us speak (Robbeets and Savelyev 2017). The heart of the Silk Road consisted of a linked string of urban centers, including Afrasiab (ancient Samarkand), Bukhara, and Paykend (Figure 1), that stretched across ancient Sogdiana-what is now Uzbekistan and Tajikistan. Some of these oasis cities were first occupied in prehistory, but overland trade peaked between the early medieval period

Received: 17 June 2021; accepted: 8 October 2021; published online

Supplementary Information The online version contains supplementary material available at https://doi.org/10. 1007/s12231-021-09531-6. 


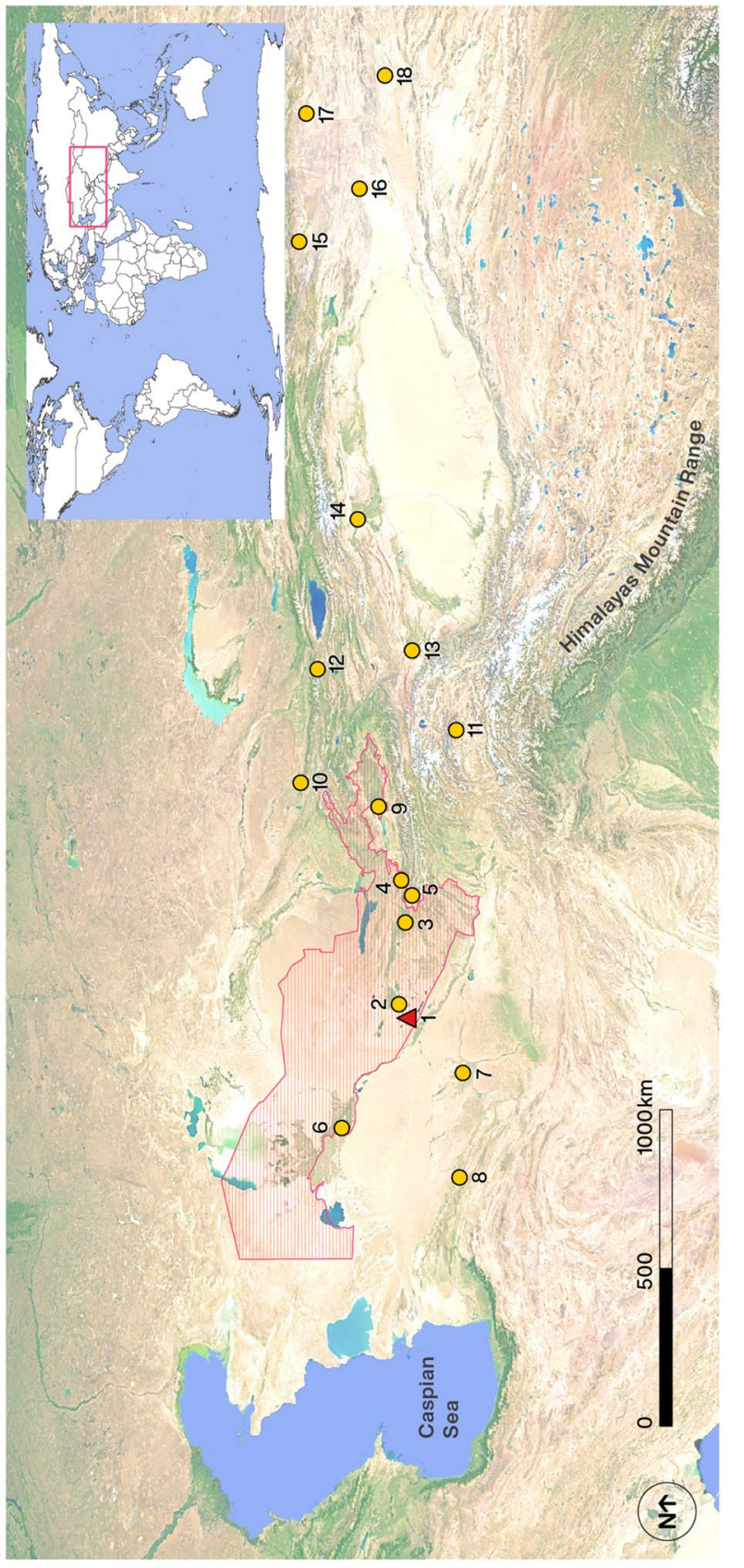


and continued until the Mongol Conquests in the year 1220 (Abazov 2008; Biran 2001).

As a trading hub, Paykend helped bridge imperial centers from China to the eastern Mediterranean-eastern Turkestan, Chach, eastern Sogdiana, and Margiana, as well as ancient Bactria/Tokharistan and the Indian subcontinent (Buryakov 1997; Omel'chenko 2013, 2019). Paykend was founded by Sogdians as a fortress in the 4th century B.C.E., and developed into a city at the transition period between late Antiquity and the Early Middle Ages, becoming a prominent entrepôt that flourished until the middle of the Qarakhanid period (Omel'chenko 2019; Semenov 2002). As an urban center, Paykend remained prosperous until the 11th century, when it was abandoned due to aridification (Narshakhi 943; Nekrasova and Torgoev 2016; Omel'chenko 2019) and a reduction in water output from the main course of the Zerafshan River on which Paykend was located (Rante and Mirzhaakhmedov 2019). Over time, the water deficit caused abandonment of numerous cities on the edges of the Bukhara Oasis. In the Tārīkh-i Bukhārā, it was claimed that Ali Arslan Khan, a Qarakhanid ruler, attempted to have a canal dug to revive the city but was unsuccessful (Narshakhi 943; Nekrasova and Torgoev 2016). Our radiocarbon dates illustrate (discussed below) that, until the end of the Qarakhanid period after the city was in decline, Rabat-4 may have continued to serve as a caravanserai or a rest stop where travelers remained for short periods before continuing their journey. It is likely that rabats in this region continued to function, due to their position at lower elevation, their economic importance, their sponsorship by the state, and the fact that they did not require as much water as a full city.

The ancient road from Amul/Amuya/Firabr to Bukhara would have been widely traveled, fostering long-distance commerce and providing incentive for the broader empire to continue protecting caravans along the eastern edges of the oasis. The heart of the ancient city would have been located a few thousand meters from the caravanserai, and would have already been in ruins by the time the Mongols arrived in Bukhara (Semenov 2002). The fact that the city has been desiccated since its abandonment provides a unique glimpse into life before the Mongol Conquests. The region itself was suitable for farming until the later part of the Qarakhanid phase, due to a complex system of lakes and canals (Omel'chenko 2019); whereas, historical sources discuss the local branch of the oasis as a microecological pocket, suggesting that between 400 and 1,100 ha of the city was located in the rural hinterland (Naymark 1992).

Historically, the Qarakhanids are thought to be the first Central Asian Islamic dynasty with rulers who had Turkic origins and a court that was run in a Turkic language (Biran 2015, 2016; Duturaeva 2016; Hua 2008; Kochnev 2006; Paul 2001; Pritsak 1951, 1953; Umnyakov 1927). At the end of the 10th century, the Qarakhanids displaced the Samanid elites, and most of the resulting multiethnic empire lived in cities in the lowlands or towns in the foothill or desert-grassland ecotones, where people actively carried out irrigated agriculture and trade (Maksudov et al. 2019). Taking over Samarkand and Bukhara, the Qarakhanid rulers invested in irrigation and urban infrastructure building. Qarakhanid rulers (khan/khagan), such as Ali Aslan Khan, supported the construction of palaces (sarai) in and around Samarkand and Bukhara; in addition, considerable reconstruction work was undertaken at Paykend (Karev 2013). Many mausoleums, minarets, madrasas, and mosques were constructed throughout the Qarakhanid territory (Arapov 2013). During the Qarakhanid period, irrigation canals were built for farming in northern Central Asia (Golden 2011). Clarke et al. (2005) stated that irrigation systems were expanded onto the floodplains and deltas between C.E. 950 and 1200; while people in Fergana and Transoxiana appear to have continued a sedentary farming lifeway (Golden 2011). Despite extensive investment in infrastructure and agriculture, the empire experienced problems before the Mongol Conquests, possibly due to the pluralistic system of government common among most of the steppe empires. Historians state that the Qarakhanids divided land among siblings, a practice historically typical of mobile pastoralists. As a result, the empire rapidly splintered and four capitals formed: Kashgar, Samarkand, Uzgen, and Balasagun. According to Starr (2013), this increasing expansiveness and decentralization was the Achilles' heel of the Qarakhanids.

Early archaeological investigation at Paykend focused on cultural artifacts and 
architecture (Baratova and Omel'chenko 2013; Mirzaakhmedov 2016; Mirzaakhmedov et al. 2016; Mukhamedzhanov et al. 1988; Omel'chenko 2013, 2019; Semenov 2002), and a dearth of data on floral and faunal remains persists from Qarakhanid sites in the region. In this study, we ask the following: 1) how did agriculture develop in the hyperarid desert during the Qarakhanid reign-a period when some historians envision an agricultural decline (e.g., Bartol'd 1963:62-63); and 2) what was the role of arboriculture and cash crops at this nodal city of the Silk Road. We present an archaeobotanical assemblage from the Qarakhanid period to test assumptions about agricultural development or decline and to explore the introduction of crops into the core of the trade routes.

\section{Paykend and Its Environment}

The site $\left(39.586244^{\circ}, 64.008709^{\circ} ; 233\right.$ masl) is located in the southwest of the Bukhara Oasis on the lower course of the Zerafshan River (Omel'chenko 2019) on the edge of the desert zone (Rante and Mirzaakhmedov 2019). Finds of 9th/10th century, exfoliated and easily breakable ceramic sherds in a depression to the southeast of Paykend, indicate that the ceramics were long exposed to water suggesting that there might have been water reaching the Paykend area from the lower Kashka-Darya River as late as the 9th/10th centuries (Stark et al. 2017). Despite an average annual rainfall ranging from 114-125 mm (Mavlyanova et al. 2005) to $160 \mathrm{~mm}$ (Rante and Mirzaakhmedov 2019), most of the oasis is currently under cultivation of fruit orchards and wheat and cotton fields (Kurbonovich 2016). The pumping of underground aquifers, loss of mountain glaciers, and heavy diversion of water from the river has dramatically changed the boundaries of the oasis over the past century and lowered the water table. However, detailed studies of botanical remains and cultivation practices can inform us as to what the local ecology would have looked like in the past.

\section{Materials and Methods}

We collected 22 sediment samples (412.5 L) from Paykend in 2019, where 20 samples were from Rabat-4 (357.5 L) and two samples were from two middens (55 L) in Shakhristan II (Figure 2). Cooking ovens, tandyrs (cylindrical clay ovens that are typical for Central Asia), and burnt deposits were sampled at Rabat-4, the urban center of the 9 th/10th centuries at Paykend (Semenov 2002). The midden samples from Shakhristan II are ideal complements to the hearth and oven contexts, which would have been regularly cleaned. We floated the samples using an overflow machine with a catchment tank system, which allowed for more rapid field processing and the reduction of water waste. All macrobotanical remains were recovered in a carbonized state. Following established protocols for archaeobotanical studies in Central Asia (Motuzaite Matuzeviciute et al. 2019; Spengler et al. 2018), light fraction was collected down to $0.355 \mathrm{~mm}$, and the heavy fraction was collected down to $1.4 \mathrm{~mm}$. Heavy fraction samples were sorted in the field and all carbonized macrobotanical remains were separated and packaged for transport. All cultural artifacts were returned to the archaeologists, while the light fractions and macrobotanical remains from the heavy fraction were sent for analysis to the Paleoethnobotany Laboratory at the Max Planck Institute for the Science of Human History in Jena, Germany.

In the laboratory, carpological remains were examined under low magnification and identified using seed identification keys (e.g., Cappers and Bekker 2013; Cappers et al. 2012; Jacomet 2006, 2012; Neef et al. 2012). The identifiable seeds and fruit parts were quantified and have been presented in the Electronic Supplementary Material (ESM) 1. Fragmented grains of free-threshing wheat (Triticum aestivum $\mathrm{L}$.) and hulled barley (Hordeum vulgare var. vulgare L.) were quantified based on Minimum Number of Individual (MNI) estimates, whereas three fragments were counted as one grain. Fragmented grains of wheat or barley that were too small to properly identify (usually less than one third of the original mass) were categorized as Cerealia. Fragments not assigned to a taxon were classified as unidentifiable. Seed fragments and 


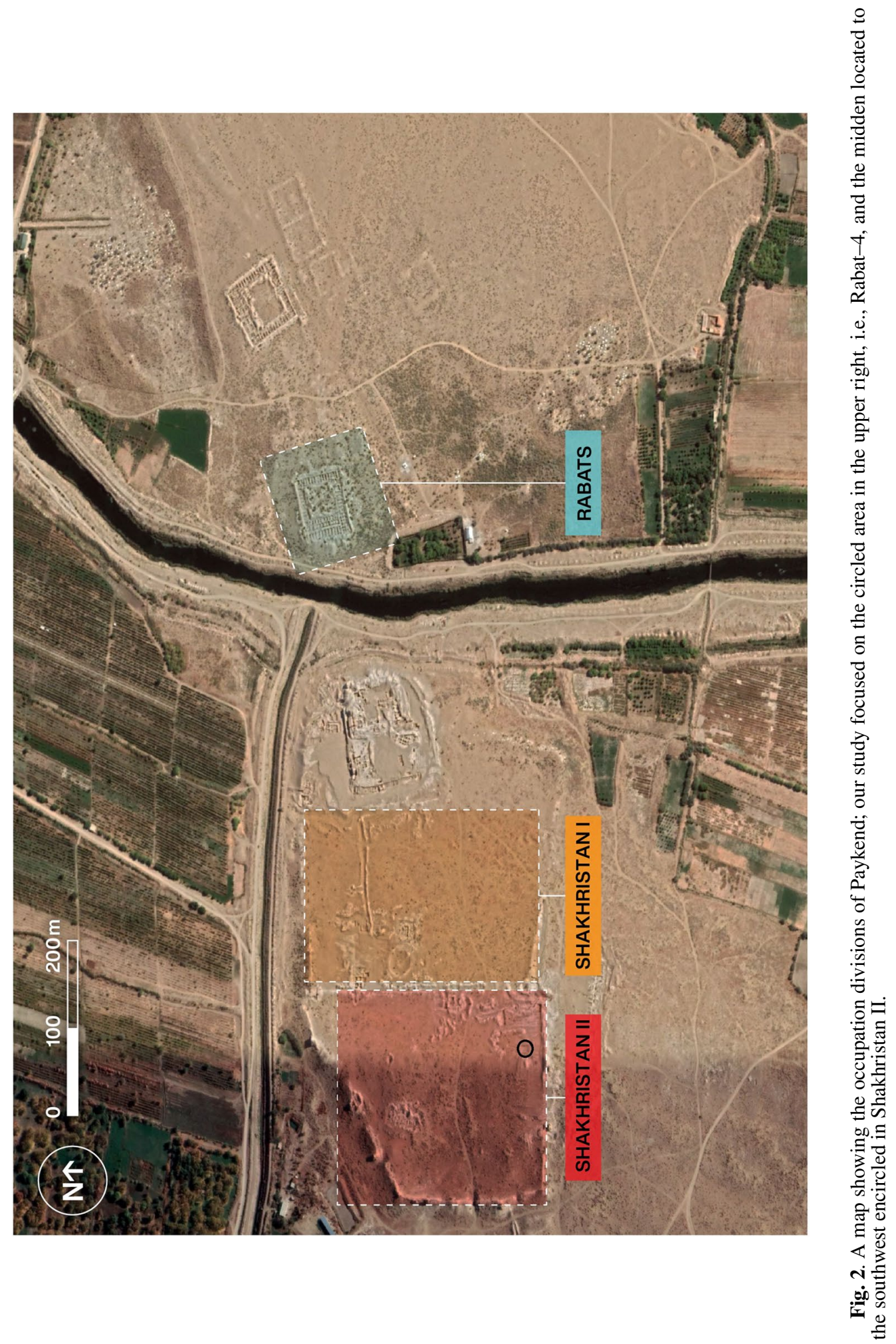


Cerealia were not added to the total counts. Nuts were represented mainly by fragmented shells, and minimum numbers estimated due to their small number and were presented as fragments in ESM 1.

Length, width, and thickness measurements were made for all whole wheat, barley, and millet grains. Grape (Vitis vinifera L.) measurement parameters were length, stalk length, chalaza position, and width (Table 1); measurements were made digitally with a Keyence VHX 6000 microscope. After identification and measurement, six samples were chosen and sent for radiocarbon dating. Barley, wheat, and broomcorn millet (Panicum miliaceum L.) grains from Rabat -4 and wheat and barley from Shakhristan II were directly dated (AMS) at the Scottish
Universities Environmental Research Centre (SUERC) Radiocarbon Dating Laboratory and calibrated using OxCal v4.4.2 software (Bronk Ramsey 2009, 2020) and the IntCal 20 curve (Reimer et al. 2020).

\section{Results}

\section{RADIOCARBON DATING}

The results of the radiocarbon dating are provided in Figure 3. The possible occupation range spans cal. C.E. 897-1223, resulting from the 2-sigma calibration. The mean $(\mu)$ of the two dates from Shakhristan II ranged from cal. C.E. 992 to 1106. A wheat grain from FS 8 dated

Table 1. Average SeEd Measurements for the MOST PROMinent Crops

\begin{tabular}{|c|c|c|c|c|c|c|c|c|c|}
\hline & Total & Whole & $\begin{array}{l}\text { Not meas- } \\
\text { urable }\end{array}$ & $\begin{array}{l}\text { Average } \\
\text { length } \\
(\mathrm{mm})\end{array}$ & $\begin{array}{l}\text { Average } \\
\text { width } \\
(\mathrm{mm})\end{array}$ & $\begin{array}{l}\text { Average } \\
\text { thickness } \\
(\mathrm{mm})\end{array}$ & $\begin{array}{l}\text { Scutellum } \\
\text { length } \\
(\mathrm{mm})\end{array}$ & $\begin{array}{l}\text { Stalk } \\
\text { length } \\
(\mathrm{mm})\end{array}$ & $\begin{array}{l}\text { Chalaza } \\
\text { position } \\
(\mathrm{mm})\end{array}$ \\
\hline Barley & 327 & 165 & 162 & 5.14 & 2.56 & 2.06 & & & \\
\hline Wheat & 368 & 178 & 190 & 3.9 & 2.48 & 2.07 & & & \\
\hline $\begin{array}{l}\text { Small } \\
\text { wheat }\end{array}$ & 86 & 40 & 46 & 2.92 & 1.79 & 1.53 & & & \\
\hline Rice & 3 & 3 & & 4.59 & 2.73 & 1.97 & & & \\
\hline $\begin{array}{l}\text { Broomcorn } \\
\text { millet }\end{array}$ & 151 & 68 & 83 & 1.88 & 1.61 & & 0.67 & & \\
\hline $\begin{array}{l}\text { Foxtail } \\
\text { millet }\end{array}$ & 68 & 25 & 43 & 1.65 & 1.47 & & 1.09 & & \\
\hline Grape & 31 & 14 & 17 & 4.95 & 3.09 & & & 1.16 & 2.45 \\
\hline
\end{tabular}

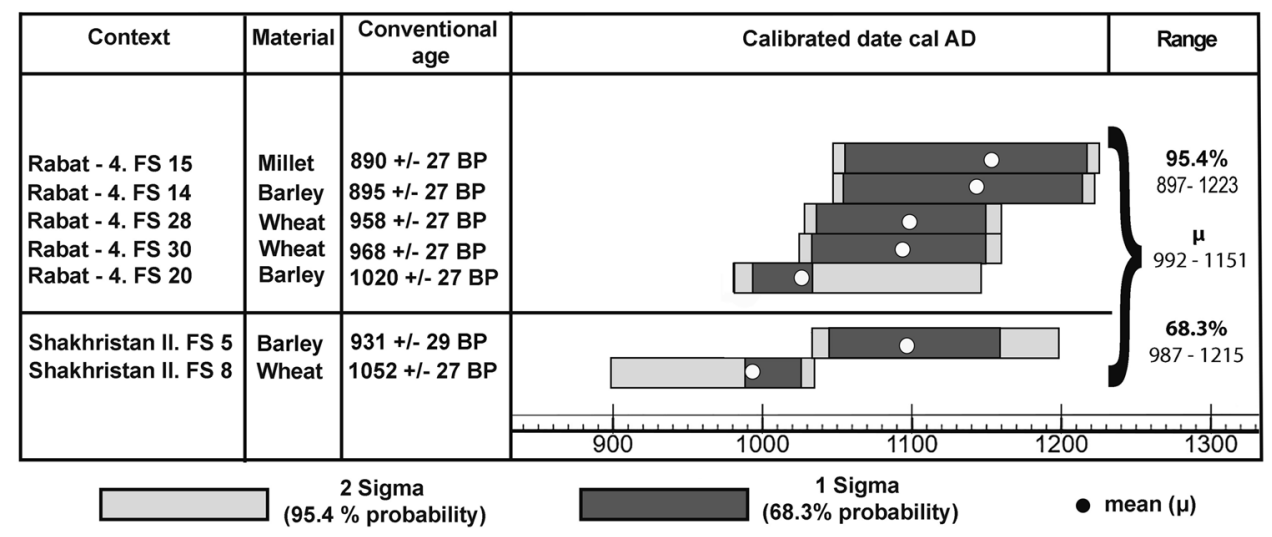

Fig. 3. Radiocarbon dates obtained on carbonized grains recovered from Rabat -4 and Shakhristan II 
between cal. C.E. 897 and 1032 (GU56000) and a barley grain from FS 5 is from between cal. C.E. 1032 and 1119 (GU56828). The mean $(\mu)$ of the four dates from Rabat -4 ranged from cal. C.E. 1023 to 1151. Barley from FS 20 dated between cal. C.E. 980 and 1148 (GU56003) and FS 14 - cal. C.E. 1045-1220 (GU56001); wheat from FS 28 is from between cal. C.E. 1028 and 1158 (GU56004) and FS 30 - cal. C.E. 1023-1158 (GU56005); and millet grains from FS 15 were dated to cal. C.E. 1034-1230 (GU56002) with $95.4 \%$ probability in Rabat-4 (see ESM 2). Based on curves on the multiple plots (Figure 3), the samples span the Qarakhanid period from the 11th and 12th centuries C.E.

\section{ARCHAEOBOtANY}

The archaeobotanical assemblage presented in this article consists of 25,646 carbonized seeds and fruit parts, as well as 1,132 unidentifiable seed fragments (ESM 1). In addition to the total sum of identified seeds, there were 319 Cerealia fragments and one legume fragment. Combined, these samples yielded 75 plant taxa, including domesticated grains and legumes, fruits and nuts, and wild herbaceous plants. Some of the wild species were only identifiable to family, suggesting that the total number of represented species is greater than the number of named taxa. Of the identifiable specimens, 1,061 seeds belonged to the group of domesticated field crops, 57 were categorized as fruits or nuts, and 24,528 were placed in the group of wild herbaceous plants. In addition to seeds and nutshell fragments, 66 free-threshing hexaploid wheat rachises, 2 possible spikelet fragments, 193 hulled barley rachises, and 4 culm nodes were recovered but were not added to the final counts. In addition to carpological remains, $648.2 \mathrm{~g}$ of wood fragments larger than $2.0 \mathrm{~mm}$ in diameter were recovered.

\section{Domesticated CRops}

Five grain crops were recovered at Paykend: free-threshing wheat, hulled barley, broomcorn millet, foxtail millet (Setaria italica [L.] P. Beauv), and rice (Oryza sativa L.). Legumes included lentils (Lens culinaris Medik.), green peas (Pisum sativum L.), and chickpeas (Cicer arietinum L.). Furthermore, seeds of flax (Linum usitatissimum L.) and cotton (Gossypium sp.) were identified in a few Rabat-4 samples.

Of the 1,061 domesticated crops, the most dominant specimen type was free-threshing wheat $(n=454)$; additionally, 65 hexaploid wheat rachis internodes (Figure 4e) were recovered. Out of 454 wheat grains, 86 of them were classified and counted separately, due to their unusually small, but not compact morphology. The small wheat grains were recovered from only two samples: one sample (FS 29) came from a tandyr oven on the southwestern side of Rabat -4 and one additional small grain came from Shakhristan II (FS 8). Wheat grains made up $42.3 \%$ of the total domesticated annual crop seeds, with a density of 1.21 grains per liter in Rabat -4 . Wheat was the most abundant crop recovered, and its ubiquity was $65 \%$ in Rabat -4 and $100 \%$ in Shakhristan II. There were 327 barley grains recovered, which all appear to be hulled; moreover, all whole barley rachis internodes resembled hulled forms. Barley grains were only recovered from Rabat-4. Although, the relative abundance (32\%) and density $(0.915$ grains per liter) of barley was less than wheat, its ubiquity (75\%) was higher. In addition to barley and wheat, 138 broomcorn and 47 foxtail millet grains were recovered. Although, millet was recovered at a lower density $(0.671$ seeds per liter) and its relative abundance was only $23.4 \%$, its ubiquity was almost $85 \%$ (Table 2 ). In addition, three rice grains were recovered from one Rabat-4 sample.

A single chickpea was handpicked from the midden in Shakhristan II (Figure 4i). Additionally, three lentils were identified, two of which came from Rabat-4 and one from Shakhristan II. Only one pea was recovered from Rabat-4, and was in a bad state of preservation, but was still identifiable. Due to the small number of seeds, the ubiquity, density, and relative abundances for legumes were lower than any of the grain crops. Cotton seeds $(n=11)$ were recovered from three samples, with a ubiquity of $15 \%$. The two samples from the tandyr ovens and the one from the hearth contained significant quantities of charcoal.

\section{FRUITS AND NuTS}

In addition to grains and legumes, fruit seeds and nutshell fragments were recovered, 


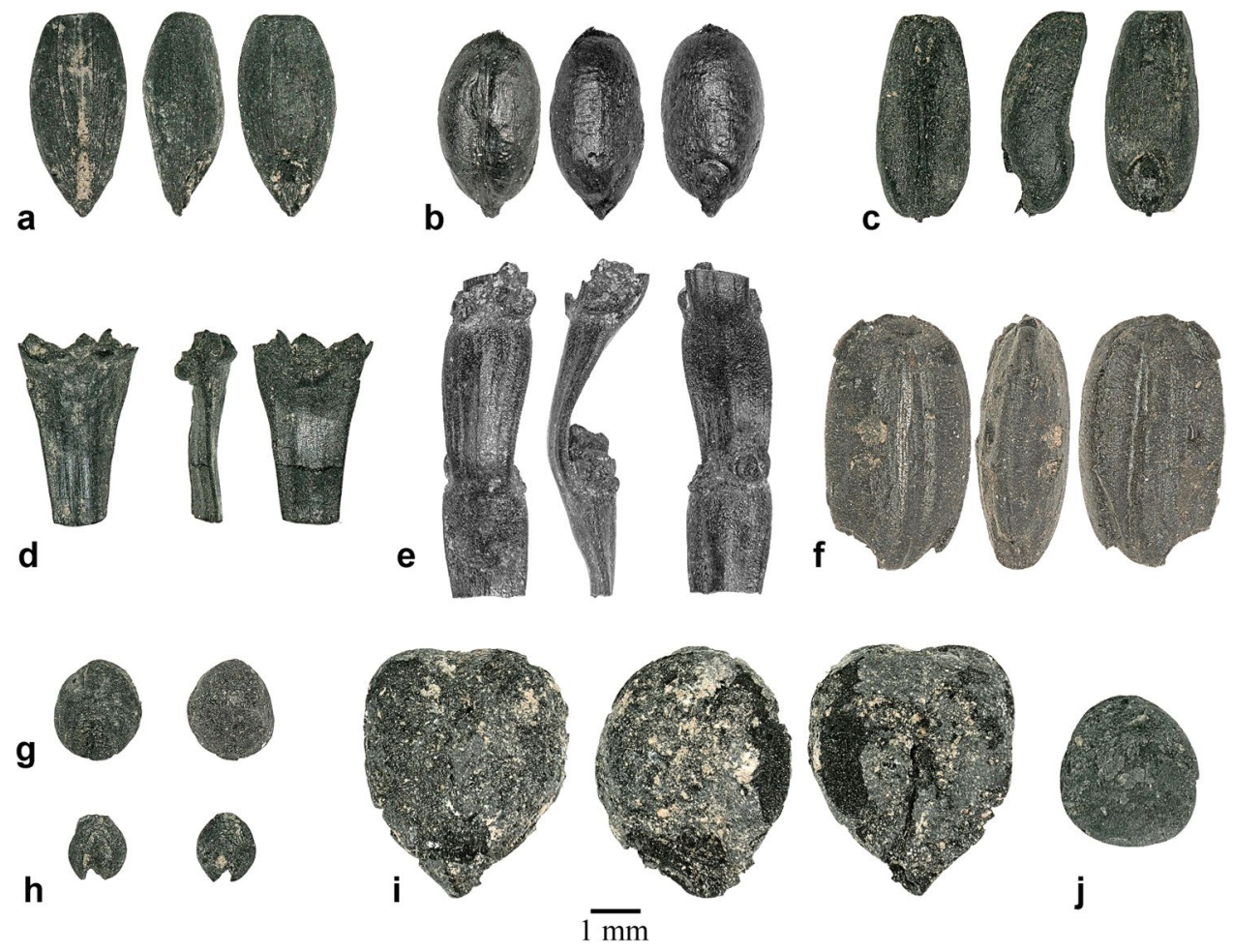

Fig. 4. a: Hordeum vulgare var. vulgare L., b: Triticum aestivum L., c: Triticum sp., d: Rachis of hulled barley, e: Rachises of free-threshing wheat, f: Oryza sativa L., g: Panicum miliaceum L., h: Setaria italica (L.) P. Beauv, i: Cicer arietinum L., and j: Lens culinaris Medik.

including seeds of sweet melons (Cucumis cf. melo L.; Figure 5a), fragments of apricot endocarp (Prunus cf. armeniaca L.; Figure 5f), fragments of walnut endocarp (Juglans regia L.; Figure $5 \mathrm{~g}-\mathrm{h}$ ), a fragment of a pistachio shell (cf. Pistacia vera L.; Figure 5e), a stone fragment of Russian olive (Elaeagnus angustifolia L.; Figure 5d), apple/pear seeds (Malus/ Pyrus; Figure 5b), and grape pips (Figure 5c). The most abundant fruit in the assemblage was grape ( $n=31$ pips), making up almost $48.4 \%$ of the recovered fruit and nut remains from Rabat-4 and $61.5 \%$ from Shakhristan II. Six melon seeds were discovered in Rabat-4 samples. Most melon seeds came from the ovens, and they were not in a good state of preservation. Nonetheless, the diagnostic features of Cucumis sp. were visible, presumably from C. melo (see Figure 5a). Also, three apple/pear seeds were recovered from the same samples as the melon and grape seeds in Rabat -4 and one seed came from Shakhristan II. They express considerable morphological variation (see Figure 5b).

There were five fragments of Prunus endocarp, but only two of them could be confidently classified as apricot stone fragments. Three walnut shell fragments were found in one sample. The pistachio shell does not have clear distinctive characteristics, but roughly resembles the shape of a pistachio shell. Most of the nutshell fragments came from Shakhristan II. In addition to all above-mentioned fruits and nuts, half of an oblong Russian olive stone was recorded from Rabat-4.

\section{Wild Herbaceous Plants}

In addition to the cultivated crops, 53 wild seed categories were recorded, belonging to 16 families. The most abundant wild seed group came from members of Amaranthaceae, which 


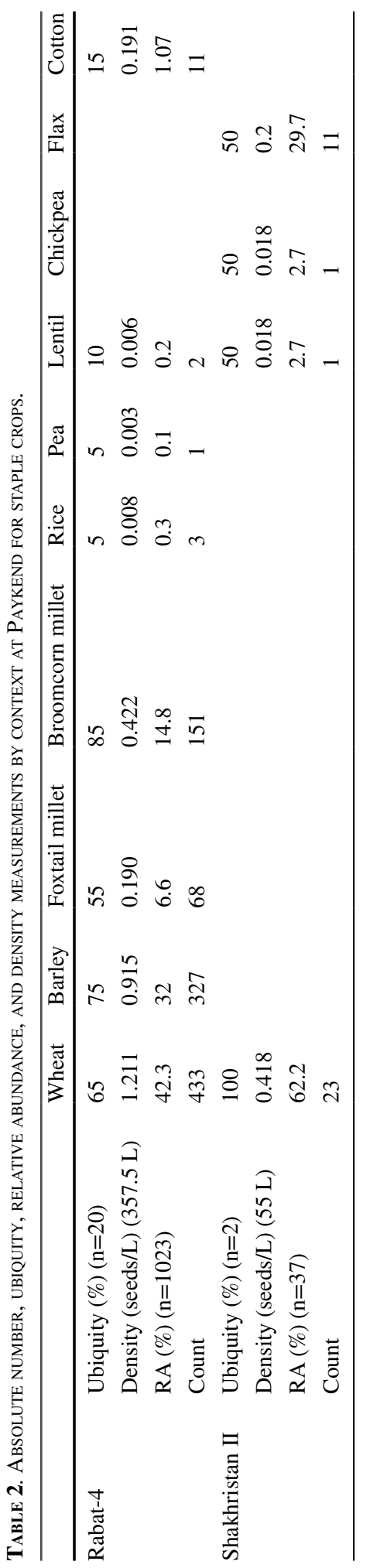

made up almost $66 \%$ of all wild seeds in Rabat-4 and $30.9 \%$ in Shakhristan II. We subdivided Amaranthaceae seeds into several categories based on morphological characteristics. Many specimens had traits that matched Chenopodium/ Atriplex spp., Suaeda spp., or Salsola type, but there were also seeds for which their genera were not identified, and they were classified as Amaranthaceae. We also subdivided Fabaceae into several categories, including Medicago/Melilotus spp., Alhagi sp., Trifolium sp., Trigonella sp., and Coronilla/Trigonella spp., which made up $11.9 \%$ of the abundance from the Rabat- 4 samples and 25.5\% from the Shakhristan II sample. The most ubiquitous and abundant types of the Fabaceae were camel thorn (Alhagi sp.) and a small herbaceous type-Medicago/Melilotus spp. Asteraceae achenes were present at a ubiquity of $90 \%$. Achenes of Asteraceae type A were narrowly obovoid and biconvex with a truncated apex - an unidentified type recovered in more than half of the Rabat-4 samples. Small Poaceae type A is the most abundant category of grass recovered in Rabat -4 . The seeds of this clade were small $(0.6-0.5 \mathrm{~mm})$, obovoid and possessed a compressed small hilum at the bottom. In addition to the small grass seeds, the category pooid was used for many of the wild grasses. The least abundant seeds were attributed to Boraginaceae; their relative abundance was $<0.1$, because only two mericarps of Heliotropium sp., five mericarps of Lithospermum arvense L., and 3 mericarps of the borage family were recovered. In addition to carbonized L. arvense, 30 mineralized seeds of this species were found in the assemblage, but they were not counted.

\section{Discussion}

\section{TAPHONOMY}

Spengler et al. (2013b) proposed several reasons for the presence of wild/weedy plant remains in the archaeobotanical assemblages: human/animal foraging, dung burning, natural dispersal, bioturbation, and seed rain. Although our samples are not large enough to make any conclusions regarding taphonomy of the samples coming from Shakhristan II, we speculate that recovered plant remains from the middens consist of kitchen waste as they include fragments 



Fig. 5. a: Cucumis cf. melo L., b: Malus/Pyrus, c: Vitis vinifera L., d: Elaeagnus angustifolia L., e: cf. Pistacia vera L., f: Prunus cf. armeniaca L., and g - h: Juglans regia L.

of economic plants. Although there are remains of wild herbaceous plants, their density is only three seeds per one liter, which is much less than in Rabat-4 where the density of wild plants made up almost 68 plant remains per liter. In addition to kitchen waste and crop-processing, the material reported from Rabat-4 is likely too rich to represent fuel residue alone. Archaeobotanical studies and experiments in Central Asia (Miller and Smart 1984; Spengler 2019a; Spengler et al. 2013b) have demonstrated that dung burning is one of the primary sources of wild herbaceous plant seeds in archaeological contexts, as many tiny seeds withstand digestion and charring. Our data illustrate that dung was used parallel to wood as fuel sources in Paykend.

\section{Agriculture in the HyPer-Arid Desert}

\section{Ecological Constraints}

This archaeobotanical study helps answer long-standing questions related to agrarian practices and environmental context. Evidence from Paykend indicates local cultivation of barley, wheat, and millet. Barley can reliably be grown on saline soil and in arid or cold conditions (Shapiro Ledley et al. 2017), as well as in nutrient-poor soils (Zohary et al. 2012), and certain varieties can be grown at extremely high altitudes (Tang et al. 2021). These qualities make barley one of the most prominent crops, grown in antiquity from the British Isles to the Japanese Archipelago. Based on archaeobotanical data (e.g., Miller 1993; Motuzaite Matuzeviciute et al. 2020, 2021b; Spengler et al. 2017) from the third to the mid-first millennia B.C.E., barley was widely cultivated, but the ratio of wheat to barley slightly shifted in favor of wheat starting in the mid-first millennium B.C.E. across Central Asia. The shift may have stemmed from improvements in irrigation systems and the greater reliance on bread wheat (Hole et al. 1969). Wheat grains recovered at Paykend varied considerably in size. In one sample (FS 29), 85 wheat grains were particularly small (Figure 6). There are many different variables that affect grain dimensions, such as different amounts of nutrients, sunlight, differing temperatures, soil moisture, altitude, latitude, etc., which can phenotypically impact development (Motuzaite Matuzeviciute et al. 2018, 2021a). There are two possible interpretations: 1) the small wheat grains could represent a plastic reaction to short-term drought stress. Water deficits reduce the mass flow of nutrients and nutrient diffusion between soil particles and 


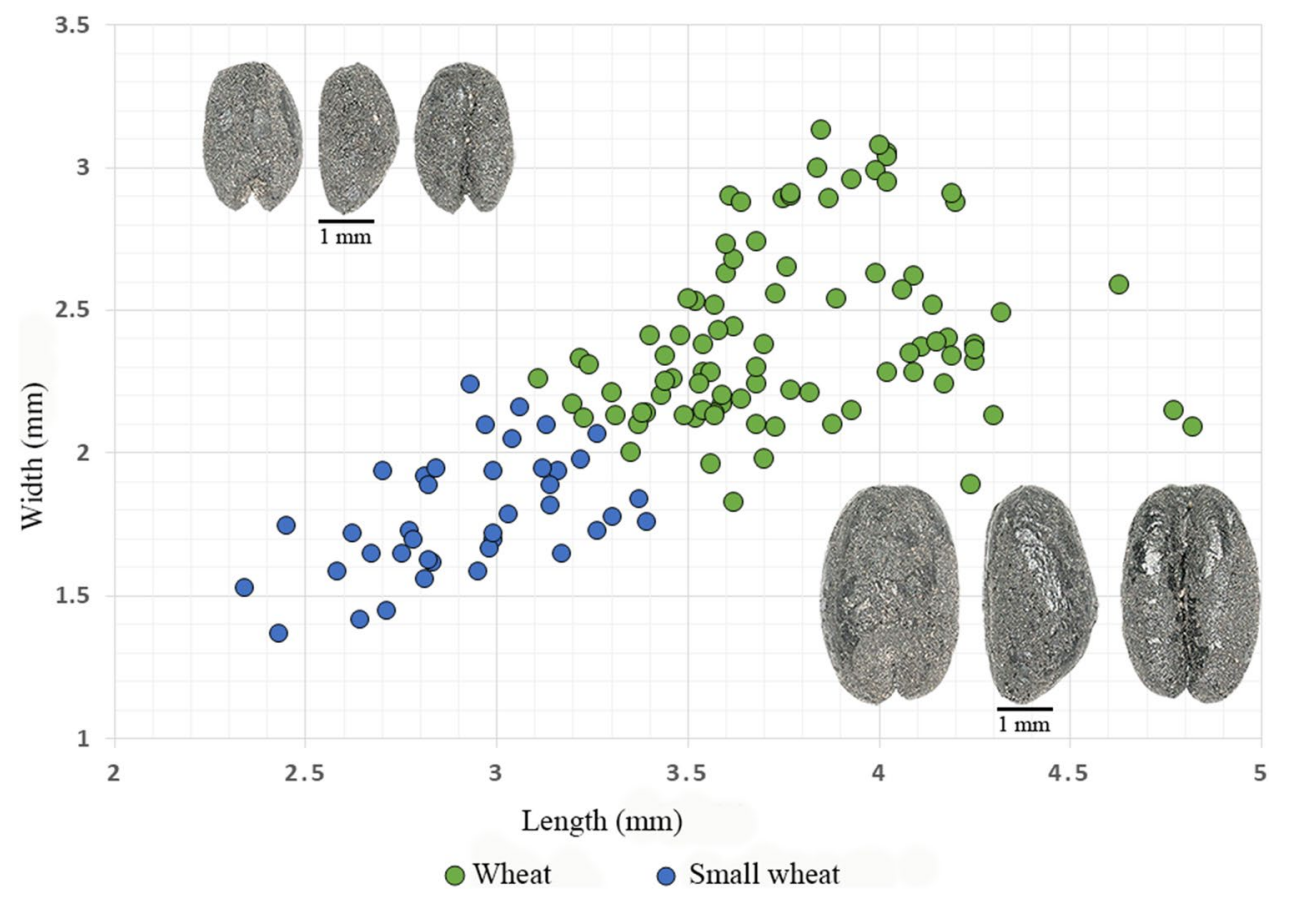

Fig. 6. Size variations of free-threshing wheat grains from sample FS29.

cause root shrinkage (Bloom et al. 1985); therefore, wheat grains might have received fewer nutrients, consequently influencing grain size. However, grain mass may vary relative to the location on the floret and immature grains can also appear either small or collapsed (Baillot et al. 2018). Therefore, 2) the small grains may represent the immature grains, possibly that might have been fed to animals and later come to the context with dung that was used as fuel.

Although wheat and rice were mentioned in historical sources as exported crops in the 5th century C.E., we argue that wheat was derived from local crop-cultivation at Paykend during the Qarakhanid period, because crop processing by-products were recovered together with grains in the samples (Fig. 4d, e). Many archaeobotanists have pointed out that "plant food that are to be traded are usually transported in a pure, fully cleaned form" (Herrmann et al. 1993:56)

\section{Risk-Reduction Strategies}

Both broomcorn and foxtail millet were present in the Paykend assemblage, despite not being identified at other Qarakhanid settlements and being rare in urban centers across Central Asia through time (Miller et al. 2016). Spengler et al. (2018) highlighted the fact that the millets were an important crop just a thousand years earlier than the samples in this study and have traditionally been associated with mobile peoples across Eurasia. Millet grains have been recovered from medieval cities further north, including Taraz (C.E. 942-1210) (Bashtannik et al. 2015), Talgar (C.E. 700-1200), Akyrtas (C.E. 900-1200), Ornok (C.E. 900-1200) (Bashtannik 2007), and in Zhuan-Tobe (9th and 10th centuries) (Bashtannik 2008). Stable isotope analysis further shows that the people living in the big cities during the medieval period were not eating considerable quantities of millet, while people in the small towns, homesteads, or living in seasonal camps were consuming the grains in substantial quantities (Hermes et al. 2018). Millet cultivation could have been beneficial for small villages and cities with poor irrigation and unreliable economies, because it would have mitigated agricultural risk and required lower labor investment than other crops. 
Additionally, the millets could have played a key role in crop-rotation cycles as a summer-dry crop (Miller et al. 2016). Pokharia et al. (2014) pointed out that millet was an important component of dryland agriculture in South Asia. Thus, millet cultivation at Paykend may have been a response to aridity in the region, due to aridification of this part of Central Asia, or simply one component in a complex multi-cropping system of rotation, possibly seasonal.

\section{Water-Demanding Crops}

Rice is currently the most consumed cereal after wheat in Uzbekistan. The oldest rice grains recovered in Central Asia come from the ancient urban site of Khalchayan in Uzbekistan, dating to the 2 nd or 3 rd century C.E. (Kushan period) (Chen et al. 2020). Archaeobotanical studies illustrate that rice has been present in Central Asia since the early first millennium C.E. (Spengler 2019a). While, according to historical sources, rice was attested in Fergana since the late 2 nd century B.C.E. (Spengler 2019a). Rice is the most water-demanding crop found at the site; taking into consideration the aridity of the area, especially around the tail end of occupation at Paykend, we think it is more likely that these three grains represent a trade item. Similar to rice, cotton is another water-demanding crop recovered at Paykend, but its presence in the form of seeds does not necessarily mean that it was grown around the city at this time, but it could have been brought from Bukhara where it was likely cultivated based on preliminary results from our ongoing project there.

\section{Arboriculture and Cash Crops at PAYKEND}

The only previous systematic archaeobotanical study of a Qarakhanid settlement was conducted on sediments from the high-elevation village of Tashbulak, in the Pamir Mountains of Uzbekistan (Maksudov et al. 2019). Tashbulak was geographically removed from the large urban centers of the political core of the empire. However, excavations at the site suggest that the occupants were directly connected into a broader Qarakhanid social network (Hermes et al. 2018; Maksudov et al. 2019). In contrast to Tashbulak, Paykend was an urban center at the political core of the empire. Moreover, Paykend and Tashbulak are located on ecologically different landscapes, but as Spengler et al. (2018) noted, fruit and nut remains found in Tashbulak had to have been cultivated at lower elevations and transported up to high elevations (ca. 2,200 masl). Spengler et al. (2018) identified seeds from stone fruits and grapes including wild capers (Capparis spinosa L.), wild cherries (Prunus subgenus Padus Forcke), wild hackberries (Celtis caucasica Willd.), as well as possibly cultivated Russian olives, sea buckthorn (Hippophae rhamnoides L.), walnuts, apples, and pistachios. Domesticated and non-native crops included apricots, grapes, melon, and peaches (Prunus persica [L.] Batsch), all of which were mainly recovered from one midden (the South unit).

Similar to Tashbulak, grapes were the most abundant fruit seeds recovered from Paykend, likely reflecting their importance in the economy (Spengler 2019b). Today, grapes are actively cultivated to the north of Paykend (Rante and Mirzaakhmedov 2019). Grapes have been cultivated in southern Central Asia since the second millennium B.C.E., and spread into the northern mountains by the mid-first millennium B.C.E. (Miller 1999; Spengler et al. 2013a, 2017; Wu et al. 2015). Although, grape cultivation is often associated with wine production (Janick et al. 2010), we can only theorize what role religions or political prohibitions may have played at the northern peripheries of the ancient Islamic world (Spengler 2019a). Additionally, grapes would have been one of the few sources of sweetness in the ancient world, also being easily stored when dried (Miller 2008).

The earliest evidence of apples in Central Asia comes from two possible Malus seeds, one found at second millennium B.C.E. Gonur in Turkmenistan (Miller 1999) and another from the later first millennium B.C.E. site of Tuzusai in Kazakhstan (Spengler et al. 2013a). Genetic and archaeobotanical research has illustrated that the origin of the apple is tied to human dispersal across Eurasia resulting in hybridization (Cornille et al. 2014); moreover, authors believe that the gene pool of modern apples is a consequence of the Silk Road. Genetic studies further suggest a center of origin for the modern apple within the Tian Shan Mountains of Kazakhstan (Harris et al. 2002; Spengler 2019b, c). The apple seeds from 
Paykend further show the importance of this fruit tree along the trans-Eurasian exchange routes.

Today, there are more than 160 local melon varieties recognized in Uzbekistan (Androlovich et al. 2020). Unlike the grape and apple, the melon is largely absent from archaeobotanical records in Central Asia until the first millennium C.E. Its seeds were reported to have been recovered in the Khoresm Oasis from Kara-Tepe, dated to the 4th or 5th centuries C.E. (Brite et al. 2017). Melons have also been illustrated on a wall painting with banqueters, dated to the 8 th century C.E., at Panjikent (Hensellek 2019). Later melon seeds have been recovered from Tashbulak (Spengler et al. 2018). There is an ongoing debate (Endl et al. 2018; Wang et al. 2020) over the origin and domestication of the melon. Wang et al. (2020), based on the published archaeological results, conclude that the sweet melon has been continuously cultivated for more than 6,000 years in China. As one example of supporting evidence, 15 wild melon (Cucumis melo ssp. agrestis Naudin) seeds were recovered at Tianluoshan in Zhejiang Province, China, from a cultural layer dated to 3640 B.C.E (Fuller et al. 2011). The melon likely spread across Central Asia from China and has been cultivated in Central Asia only since the medieval period. Later, it appears to have dispersed to Europe by a mostly overland route from Central Asia (Paris et al. 2012).

The identification of apricots at Tashbulak, in combination with their historical importance in Central Asia, suggests that the smooth-shelled Prunus fragments at Paykend are likely apricots. Bukhara has a specific ancient variety of apricot that has a small, sweet pericarp and a non-bitter seed; they are often sold as nuts in the markets and added to jams. Moreover, it is a major crop in the Zerafshan region and grows around Paykend today. There is a longstanding and unresolved debate over whether the apricot originated in the Caucasus, East Asia, or both (Decroocq et al. 2016; Vavilov 1950; Weisskopf and Fuller 2014). Fuller and Stevens (2019) concluded that the "cultivated apricot originates in China" and was first dispersed outside of China during the second millennium B.C.E. (Stevens et al. 2016). But recent genetic work (Liu et al. 2019b) suggests a polyphyletic origin, with up to three independent domestication events: Southern Central Asian, European, and Chinese cultivated apricot lineages

Despite the small number of nutshell fragments at Paykend, nuts were commercially important along the Silk Road; for example, markets of pistachio nuts "Bazar of the pista-shikanan" were mentioned in historical Tarikh-i Bukhara (Narshakhi 943:54), which probably was a specialized bazaar (market) for the sale of pistachio nuts, situated just outside of the early-medieval city walls. Ecologically, it is unlikely that pistachios were cultivated in the desert near Paykend, but they could have been cultivated on the slopes of the mountains less than $100 \mathrm{~km}$ away (Hormaza et al. 1994; Miller 1999; Spengler 2019b; Spengler et al. 2018; Zohary et al. 2012). The Central Asian mountains, spanning from the Tian Shan, Central Pamir-Alay, and south to the Kopetdag, were likely covered in open-canopy forests of shrubby trees in prehistory (Kayimov et al. 2011; Khanazarov et al. 2009). Pistachio shell fragments were also found at the second millennium B.C.E. sites of Sarazm in Uzbekistan (Spengler and Willcox 2013), Shortughai in Afghanistan (Willcox 1991a), and Djarkutan in Turkmenistan (Miller 1999).

Wild walnut forests grow across a wide geographic range, from Xinjiang in Western China to the Caucasus (Pollegioni et al. 2017; Spengler 2019b; Zohary et al. 2012) and Southern Europe (Renfrew 1973). The center of origin for the cultivated walnut presumably covers much or all of its wild range (Leslie and McGranahan 1992; Molnar et al. 2011; Zeven and De Wet 1982), and they likely followed a hybridization pathway to domestication. Linguistic evidence suggests that walnut cultivation spread into East Asia from Southwest Asia along the Silk Road (Spengler 2019b). Paralleling the proposed domestication for the apple, a multiproxy study of genetic, historic, and linguistic data revealed that a "gene corridor" following the trans-Eurasian trade routes may be responsible for the domestication of this arboreal crop as people spread specimens across Eurasia during the first millennium B.C.E. (Pollegioni et al. 2014, 2015).

The domestication of the Russian olive remains enigmatic, due to a lack of research, but the limited archaeobotanical data suggest 
that it was also cultivated along the Silk Road (Spengler 2019b). The earliest archaeobotanical Elaeagnus pits come from the site of Aknashen in Armenia, dating to the sixth millennium B.C.E. (Badalyan et al. 2010; Hovsepyan and Willcox 2008). Other reported finds come from the third millennium B.C.E. at Sarazm in Tajikistan (Spengler and Willcox 2013), the second millennium B.C.E. in Afghanistan at Shortughai (Willcox 1991a), and in Uzbekistan at the Sapallitepa settlement (Askarov 1972). Askarov (1972) mentioned Russian olive pits recovered with grape pips from the bottom of jars found in a burial within the Sapallitepa complex; he proposed that Russian olive was added to accelerate fermentation of alcoholic drinks. Russian olive stones were also recovered from western Iran in the Chehrabad salt mines, dated to the middle of the first millennium C.E. (Aali et al. 2014) and at the medieval sites of Tashbulak in Uzbekistan (Spengler et al. 2018) and Areni-1 in Armenia (Smith et al. 2014). Wood remains from Elaeagnus sp. trees have been recovered from archaeological sites dating to the early six th millennium B.C.E. (Decaix et al. 2016) and the fifth millennium B.C.E. (Berthon et al. 2013) in Azerbaijan, and in the third to second millennia B.C.E. in Syria, Tajikistan, and Afghanistan (Willcox 1991b). Wood remains have also been reported from ancient cities along the Heihe River Basin in western China, dated to the first millennium C.E. (Liu et al. 2019a) and as far west as Eastern Anatolia by the early medieval period (Willcox 1974). While Russian olive is cultivated in western China today, the native $E$. pungens grows in arid parts of the region and complicates the identification of the ancient dispersal of the crop based on archaeological wood fragments. Today Russian olive trees are not widely cultivated for commercial trade, but are grown in Pakistan (Azmat et al. 2020) and Uzbekistan.

In this paper, we focus on the presence and absence of taxa in the Paykend assemblage, and do not speculate about the importance of any of these species in the economy. Walnuts, apricots, and apples are actively cultivated in the Bukhara Oasis today, and the region is well-known for its grapes. Unlike many of these arboreal fruits, the melon is more water demanding and requires frequent irrigation (Balliu and Sallaku 2017); melons are not currently cultivated on a large scale near Paykend, but are imported in large quantities each year. We speculate that melons, as with the pistachio, were likely imported to the site from the foothills in the past. Hypothetically, pistachios could have been transported to Paykend from the slopes of the Pistalitau ridge (pista means pistachio in Uzbek and tau or too is a mountain in Turkic). According to Arandrenko (1889:658), Bukhara, Tashkent, and Khiva were historically supplied with pistachios from the region of Pistalitau that bordered Tuzkan Lake.

Nuts and dried fruits have been cash crops (Sherratt 1999) along the Silk Road for millennia, and we suggest that at least some of the remains found at Paykend may have been imported and historically served as commodities, capital, and tribute (e.g., Frye 2005). In the accounts of Ibn Fadlan, during his 10th century C.E. expedition across Eurasia (Frye 2005), he notes spices, millets, dried fruits, and nuts being offered as gifts at Central Asian towns.

\section{Conclusion}

Cereals and legumes, notably chickpeas, lentils, barley, wheat, and broomcorn and foxtail millet, appear to have been prominent crops during the Qarakhanid period in the Bukhara Oasis, and rice and some fruits were likely imported. Due to the hyper-arid environment, dryland farming was likely integrated into an adaptive agricultural system at Paykend during the middle of the Qarakhanid reign. The millet, a drought tolerant crop, could represent a risk-reduction strategy in response to aridity in the region. Millet cultivation could also be a response to crisis in agriculture, as described by Bartol'd (1963:62-63) and in the Tārīkh-i Bukhārā (Narshakhi 943), due to desertification. However, the wide diversity of other crops and fruit remains demonstrate that, despite the aridity, agriculture continued to be one of the most important economic activities in the Qarakhanid period. The remains of fruits and nuts could represent exchange or, in certain cases, local cultivation. Although it is well established, both historically and archaeologically, that trade of goods took place along the Silk Road, the archaeobotanical assemblage demonstrates that fruits and nuts were commodities at Paykend. 
For example, pistachio nuts and possibly apples, were more likely to have been imported from the foothills than cultivated in the arid summer heat, the presence of rice and cotton also hints to links between the desert and the more humid foothills. Our data add an important component to the story of human adaptation and success in the Central Asian deserts and the globalization of the ancient world.

\section{Acknowledgements}

Special thanks to Traci Billings (Max Planck Institute for the Science of Human History) and Zhuldyz Tashmanbetova (Washington University in St. Louis) for their contribution and help in the field. We also want thank Hans Sell for his help with maps production. We would like to thank our editor and reviewers for their comments and excellent suggestions. Archaeobotanical research was funded by the International Max Planck Research Schools for the Science of Human History and the European Research Council, grant number 851102, Fruits of Eurasia: Domestication and Dispersal (FEDD). All data generated or analyzed during this study are included in this published article and its supplementary information files.

Funding Open Access funding enabled and organized by Projekt DEAL.

Open Access This article is licensed under a Creative Commons Attribution 4.0 International License, which permits use, sharing, adaptation, distribution and reproduction in any medium or format, as long as you give appropriate credit to the original author(s) and the source, provide a link to the Creative Commons licence, and indicate if changes were made. The images or other third party material in this article are included in the article's Creative Commons licence, unless indicated otherwise in a credit line to the material. If material is not included in the article's Creative Commons licence and your intended use is not permitted by statutory regulation or exceeds the permitted use, you will need to obtain permission directly from the copyright holder. To view a copy of this licence, visit http://creativecommons.org/licen ses/by/4.0/.

\section{References}

Aali, A., A. Abar, N. Boenke, A. Bouwman, R. Khoshraftar, J. Krug-Ochmann, M. Le Bailly, K. Link, M. Mashkour, G. Mowlawi, M. Nezamabadi, L. Ohrstrom, F. Ruhli, T. Stollner, and C. Warinner. 2014. Extended research report on the Chehrābād
Salt Mine Project 2010-2013. Bochum, Germany: Deutches Bergbau-Museum Bochum.

Abazov, R. 2008. Palgrave concise historical atlas of Central Asia. London: Macmillan.

Androlovich, R., S. Madiyarovich, and M. Urinbaevana. 2020. Melon and its enviromental characteristics. Journal of Critical Reviews 7:480-490. https://doi. org/10.31838/jcr.07.02.91.

Arandarenko, G. 1889. Досуги в Туркестане. 18741889 (Leisure in Turkestan. 1874-1889). St. Petersburg, Russia: Printing house of M. M. Stasyulevich.

Arapov, A. V. 2013. The architecture of Uzbekistan (9th15th centuries). In: The artistic culture of Central Asia and Azerbaijan in the 9th-15th centuries, eds., K. Baypakov, Sh. Pidaev, and A. Khakimov, 159-215. Tashkent, Uzbekistan: IICAS.

Askarov, A. 1972. Древнеземледельческая культура эпохи бронзы юга Узбекистана (Ancient agricultural culture of the Bronze Age in the south of Uzbekistan). Tashkent, Uzbekistan: Fan.

Azmat, M. A., A. A. Khan, I. A. Khan, A. Buerkert, and M. Wiehle. 2020. Morphology, biochemistry, and management of Russian olive (Elaeagnus angustifolia L.) accessions in Gilgit-Baltistan, northern Pakistan. Journal of Agriculture and Rural Development in the Tropics and Subtropics 121(1):151-160.

Badalyan, R. S., A. A. Harutyunyan, R. Hovsepyan, C. Chataigner, F. L. E. Mort, J. Chabot, J. E. Brochier, A. Balasescu, and V. Radu. 2010. The settlement of Aknashen-Khatunarkh, a Neolithic site in the Ararat plain (Armenia): Excavation results 2004-2009. TUBA-AR 13:185-218.

Baillot, N., C. Girousse, V. Allard, A. Piquet-Pissaloux, and J. Le Gouis. 2018. Different grain-filling rates explain grain-weight differences along the wheat ear. PLOS ONE 13:e0209597. doi: https://doi.org/ 10.1371/journal.pone.0209597.

Balliu, A. and G. Sallaku. 2017. Early production of melon, watermelon and squashes in low tunnels. In: Good agricultural practices for greenhouse vegetable production in the South East European countries, eds., W. Baudoin, A. Nersisyan, A. Shamilov, A. Hodder, D. Gutierrez, S. D. Pascale, S. Nicola, N. Gruda, L. Urban, and J. Tanny, 341-352. Rome: FAO.

Baratova, L. and A. Omel'chenko. 2013. Новый клад бухархудатских монет из Пайкенда. (New hoard of Bukhar Khudats coins from Paikend). Saint Petersburg, Russia: Nestor-Istoriia.

Bartol'd, V. 1963. Сочинение I: Туркестан в эпоху монгольского нашествия (Essay I: Turkestan during the Mongol invasion). Moscow: Izdatel'stvo Vostochnoy Literatury.

Bashtannik, S. V. 2007. Земледельческая культура Южного Казахстана эпохи средневековья 
[Medieval agriculture of South Kazakhstan]. Kemerovo, Russia: KemGUKI Publ.

. 2008. Археоботанические исследования на средневековых памятниках долины реки Арысь (Archaeobotanical research at medieval sites in the Arys River valley). Archeology, Ethnography, and Anthropology of Eurasia 33(1):85-92.

Bashtannik, S., D. Voyakin, and R. Buranbaev. 2015. Археоботанические исследования цитадели средневекового городища Тараз в 2014 г. (Archaeobotanical studies of the citadel of the medieval settlement Taraz in 2014). Bulletin of Archaeology, Anthropology and Ethnography 2(29):178-182.

Berthon, R., A. Decaix, Z. E. Kovács, W. Van Neer, M. Tengberg, G. Willcox, and T. Cucchi. 2013. A bioarchaeological investigation of three late Chalcolithic pits at Ovçular Tepesi (Nakhchivan, Azerbaijan). Environmental Archaeology 18(3):191-200.

Biran, M. 2001. Qarakhanid studies. A view from the Qara Khitai edge. Cahiers d'Asie centrale 9:77-89.

- 2016. Karakhanid Khanate. In: The encyclopedia of empire, eds., J. MacKenzie, N. Dalziel, M. Charney, and N. Doumanis, 1-2. Oxford, United Kingdom: John Wiley \& Sons, Ltd.

- 2015. The Qarakhanids eastern exchange: Preliminary notes on the Silk Roads in the eleventh and twelfth Centuries. In: Complexity of interaction along the Eurasian Steppe Zone in the first millennium CE, eds., J. Bemmann and $M$. Schmauder, 575-595. Bonn: Rheinische FriedrichWilhelms Universität Bonn.

Bloom, A. J., F. S. Chapin III, and H. A. Mooney. 1985. Resource limitation in plants-An economic analogy. Annual Review of Ecology and Systematics 16(1):363-392.

Brite, E. B., G. Khozhaniyazov, J. M. Marston, M. Negus Cleary, and F. J. Kidd. 2017. Kara-tepe, Karakalpakstan: Agropastoralism in a Central Eurasian oasis in the 4 th $/ 5$ th century A.D. transition. Journal of Field Archaeology 42(6):514-529. https://www.tandfonline.com/doi/full/10.1080/ 00934690.2017.1365563.

Bronk Ramsey, C. 2009. Bayesian analysis of radiocarbon dates. Radiocarbon 51(1):337-360.

—_. 2020. OxCal 4.4. https://c14.arch.ox.ac.uk/ oxcal/OxCal.html.

Buryakov, Y. 1997. Бухара на караванных путях Хорасана и Мавераннахра (Bukhara along the caravan routes of Khorasan and Mavarannahr). In: Общественные Науки в Узбекистане (Social sciences in Uzbekistan), eds., U. Parpieva and 1. Turina, 45-52. Tashkent, Uzbekistan: Fan.

Cappers, R. T. J. and R. M. Bekker. 2013. A manual for the identification of plant seeds and fruits. Groningen, the Netherlands: Barkhuis \& Groningen University Library.
Cappers, R. T. J., R. M. Bekker, and J. E. A. Jans. 2012. Digital seed atlas of the Netherlands. Groningen, the Netherlands: Barkhuis \& Groningen University Library.

Chen, G., X. Zhou, J. Wang, J. Ma, M. Khasannov, N. Khasanov, R. N. Spengler, A. Berdimurodov, and X. Li. 2020. Kushan period rice in the Amu Darya Basin: Evidence for prehistoric exchange along the southern Himalaya. Science China Earth Sciences 63(6):841-851.

Clarke, D., R. Sala, J. Deom, and E. Meseth. 2005. Reconstructing irrigation at Otrar Oasis, Kazakhstan, C.E. 800-1700. Irrigation and Drainage: The Journal of the International Commission on Irrigation and Drainage 54(4):375-388.

Cornille, A., T. Giraud, M. J. M. Smulders, I. RoldánRuiz, and P. Gladieux. 2014. The domestication and evolutionary ecology of apples. Trends in Genetics 30(2):57-65.

Damgaard, P.B. De, N. Marchi, S. Rasmussen, M. Peyrot, G. Renaud, T. Korneliussen, J. V. Moreno-Mayar, M. W. Pedersen, A. Goldberg, E. Usmanova, N. Baimukhanov, V. Loman, L. Hedeager, A. G. Pedersen, K. Nielsen, G. Afanasiev, K. Akmatov, A. Aldashev, A. Alpaslan, G. Baimbetov, V. I. Bazaliiskii, A. Beisenov, B. Boldbaatar, B. Boldgiv, C. Dorzhu, S. Ellingvag, D. Erdenebaatar, R. Dajani, E. Dmitriev, V. Evdokimov, K. M. Frei, A. Gromov, A. Goryachev, H. Hakonarson, T. Hegay, Z. Khachatryan, R. Khaskhanov, E. Kitov, A. Kolbina, T. Kubatbek, A. Kukushkin, I. Kukushkin, N. Lau, A. Margaryan, I. Merkyte, I. V. Mertz, V. K. Mertz, E. Mijiddorj, V. Moiyesev, G. Mukhtarova, B. Nurmukhanbetov, Z. Orozbekova, I. Panyushkina, K. Pieta, V. Smrčka, I. Shevnina, A. Logvin, K.-G. Sjögren, T. Štolcová, A. M. Taravella, K. Tashbaeva, A. Tkachev, T. Tulegenov, D. Voyakin, L. Yepiskoposyan, S. Undrakhbold, V. Varfolomeev, A. Weber, M. A. Wilson Sayres, N. Kradin, M. E. Allentoft, L. Orlando, R. Nielsen, M. Sikora, E. Heyer, K. Kristiansen, and E. Willerslev. 2018. 137 ancient human genomes from across the Eurasian steppes. Nature 557(7705):369-374.

Decaix, A., E. Messager, M. Tengberg, R. Neef, B. Lyonnet, and F. Guliyev. 2016. Vegetation and plant exploitation at Mentesh Tepe (Azerbaijan), 6th-3rd millennium B.C.E. initial results of the archaeobotanical study. Quaternary International 395:19-30. doi: https://doi.org/10.1016/j.quaint. 2015.02.050.

Decroocq, S., A. Cornille, D. Tricon, S. Babayeva, A. Chague, J. Eyquard, R. Karychev, S. Dolgikh, T. Kostritsyna, and S. Liu. 2016. New insights into the history of domesticated and wild apricots and its contribution to Plum pox virus resistance. Molecular Ecology 25(19):4712-4729. 
Duturaeva, D. 2016. Between the Silk and Fur Roads: The Qarakhanid diplomacy and trade. Orientierungen. Zeitschrift Zur Kultur Asiens 28(1):173-212.

Endl, J., E. G. Achigan-Dako, A. K. Pandey, A. J. Monforte, B. Pico, and H. Schaefer. 2018. Repeated domestication of melon (Cucumis melo) in Africa and Asia and a new close relative from India. American Journal of Botany 105(10):1662-1671.

Frankopan, P. 2015. The Silk Roads: A new history of the world. London: Bloomsbury Publishing.

Frye, R. 2005. Ibn Fadlan's journey to Russia: A tenthcentury traveler from Baghad to the Volga River. Princeton, New Jersey: Markus Wiener Publishers.

Fuller, D., L. Qin, Z. Zhao, Y. Zheng, L. Hosoya, X. Chen, and G. Sun. 2011. Archaeobotanical analysis at Tianluoshan: Evidence for wild-food gathering, rice cultivation and the process of the evolution of morphologically domesticated rice. [in Chinese]. Beijing: Wenwu Press.

Fuller, D. Q. and C. J. Stevens. 2019. Between domestication and civilization: The role of agriculture and arboriculture in the emergence of the first urban societies. Vegetation History and Archaeobotany 28:263-282. doi: https://doi.org/10.1007/ s00334-019-00727-4.

Golden, P. 2011. Central Asia in world history. Oxford/ New York: Oxford University Press.

Harris, S. A., J. P. Robinson, and B. E. Juniper. 2002. Genetic clues to the origin of the apple. Trends in Genetics 18(8):426-430.

Hensellek, B. 2019. A Sogdian drinking game at Panjikent. Iranian Studies 52(5):837-857.

Hermes, T. R., M. D. Frachetti, E. A. Bullion, F. Maksudov, S. Mustafokulov, and C. A. Makarewicz. 2018. Urban and nomadic isotopic niches reveal dietary connectivities along Central Asia's Silk Roads. Scientific Reports 8(5177):1-11.

Herrmann, G., V. M. Masson, and K. Kurbansakhatov. 1993. The International Merv Project, preliminary report on the first season (1992). Iran 31:39-62. doi: https://doi.org/10.2307/4299886.

Hole, F., K. V. Flannery, and J. A. Neely. 1969. Prehistory and human ecology of the Deh Luran Plain. Ann Arbor, Michigan: University of Michigan Press.

Hormaza, J. I., L. Dollo, and V. S. Polito. 1994. Determination of relatedness and geographical movements of Pistacia vera (Pistachio; Anacardiaceae) germplasm by RAPD analysis. Economic Botany 48:349-358. doi: https://doi.org/10.1007/BF028 62231.

Hovsepyan, R. and G. Willcox. 2008. The earliest finds of cultivated plants in Armenia: Evidence from charred remains and crop processing residues in pisé from the Neolithic settlements of Aratashen and Aknashen. Vegetation History and Archaeobotany 17:63-71. doi: https://doi.org/10.1007/ s00334-008-0158-6.
Hua, T. 2008. The Muslim Qarakhanids and their invented ethnic identity. In: Islamisation de l'Asie Centrale, ed., É. de La Vaissière, 339-350. Paris: Assoc. pour l'Avancement des etudes Iraniennes.

Jacomet, S. 2006. Identification of cereal remains from archaeological sites. Basel, Switzerland: IPAS.

. 2012. Archaeobotany: Analyses of plant remains from waterlogged archaeological sites. Oxford, United Kingdom: Oxford University Press.

Janick, J., M. C. Daunay, and H. Paris. 2010. Horticulture and health in the Middle Ages: Images from the Tacuinum Sanitatis. HortScience 45(11):1592-1596.

Karev, Y. 2013. From tents to city: The royal court of the Western Qarakhanids between Bukhara and Samarqand. In: Turko-Mongol rulers, cities and city life, ed., D. Durand-Guédy, 99-147. Leiden: Brill.

Kayimov, A., R. Sultanov, and G. Chernova. 2011. Pistachia in Central Asia. In: Towards a comprehensive documentation and use of pistacia genetic diversity in Central and West Asia, North Africa and Europe: Report of the IPGRI Workshop, eds., S. Padulosi and A. Hadj- Hassan, 49-55. Irbid, Jordan: International Plant Genetic Resources Institute.

Khanazarov, A. A., G. M. Chernova, A. M. Rakhmonov, L. V. Nikolyi, E. Ablaeva, D. E. Zaurov, T. J. Molnar, S. W. Eisenman, and C. R. Funk. 2009. Genetic resources of Pistacia vera $\mathrm{L}$. in Central Asia. Genetic Resources and Crop Evolution 56:429-443. doi: https://doi.org/10.1007/ s10722-009-9419-1.

Kochnev, В. 2006. Нумизматическая история Караханидского Каганата (991-1209 гг.) (Numismatic history of the Karakhanid Kaganate (991-1209). Moscow: Sofia.

Kurbonovich, H. 2016. The alien fraction of the flora of Bukhara oasis. Stapfia 105(1):92-98.

Leslie, C. and G. McGranahan. 1992. Micropropagation of Persian walnut (Juglans regia L.). In: High-Tech and Micropropagation II, ed., Y. P. S. Bajaj, 136-150. Berlin: Springer.

Liu, F., Y. Yang, Z. Shi, M. J. Storozum, and G. Dong. 2019a. Human settlement and wood utilization along the mainstream of Heihe River basin, northwest China in historical period. Quaternary International 516:141-148. doi: https://doi.org/ 10.1016/j.quaint.2018.05.033.

Liu, S., A. Cornille, S. Decroocq, D. Tricon, A. Chague, J. Eyquard, W. Liu, T. Giraud, and V. Decroocq. 2019b. The complex evolutionary history of apricots: Species divergence, gene flow and multiple domestication events. Molecular Ecology 28(24):5299-5314.

Maksudov, F., E. Bullion, E. R. Henry, T. Hermes, A. M. Merkle, M. D. Frachetti, C. Baumer, and M. Novák. 2019. Nomadic urbanism at Tashbulak: A new highland town of the Qarakhanids. In: Urban 
cultures of Central Asia from the Bronze Age to the Karakhanids: Learnings and conclusions from new archaeological investigations and discoveries, eds., C. Baumer and M. Novák, 283-306. Wiesbaden, Germany: Harrassowitz.

Mavlyanova, R., A. Rustamov, R. Khakimov, A. Khakimov, M. Turdieva, and S. Padulosi. 2005. Melons of Uzbekistan. Rome: IPGRI.

Miller, N. 1993. Preliminary archaeobotanical results from the 1989 excavation at the Central Asian site of Gonur Depe, Turkmenistan. Information Bulletin 19(1):149-163.

Miller, N. F. 1999. Agricultural development in western Central Asia in the Chalcolithic and Bronze Ages. Vegetation History and Archaeobotany 8:13-19. doi: https://doi.org/10.1007/BF020 42837.

2008. Sweeter than wine? The use of the grape in early western Asia. Antiquity 82(318):937-946.

Miller, N. F. and T. L. Smart. 1984. Intentional burning of dung as fuel: A mechanism for the incorporation of charred seeds into the archaeological record. Journal of Ethnobiology 4(1):15-28.

Miller, N. F., R. N. Spengler, and M. Frachetti. 2016. Millet cultivation across Eurasia: Origins, spread, and the influence of seasonal climate. The Holocene 26(10):1566-1575.

Mirzaakhmedov, D., A. Omel'chenko, A. Torgoev, N. Saparov, L. Smirnov, S. Mirzaakhmedov, N. Sobirov, A. Gorin, V. Mokroborodov, and A. Kulish. 2016. Работы Бухарской Археологической Экспедиции в 2013-2014 гг. (Works of Bukhara Archaeological Expedition in 2013-2014). In: Archaeological researches in Uzbekistan 10, ed., A. E. Berdimuradov, 248-266. Samarkand, Uzbekistan:The Academy of Science in Republic of Uzbekistan.

Mirzaakhmedov, S. D. 2016. The Ribāṭ-caravanserais from the eastern suburbs of Paykand. Archaeological and historical aspects. Journal of Inner Asian Art and Archaeology 7:109-123. doi: https://doi. org/10.1484/J.JIAAA.4.2017006.

Molnar, T. J., D. E. Zaurov, J. M. Capik, S. W. Eisenman, T. Ford, L. V. Nikolyi, and C. R. Funk. 2011. Persian walnuts (Juglans regia L.) in Central Asia. Annual Report of the Northern Nut Growers Association 101(1): 56-69.

Motuzaite Matuzeviciute, G., A. Abdykanova, S. Kume, Y. Nishiaki, and K. Tabaldiev. 2018. The effect of geographical margins on cereal grain size variation: Case study for highlands of Kyrgyzstan. Journal of Archaeological Science: Reports 20:400410. doi: https://doi.org/10.1016/j.jasrep.2018.04. 037.

Motuzaite Matuzeviciute, G., T. R. Hermes, B. MirMakhamad, and K. Tabaldiev. 2020. Southwest Asian cereal crops facilitated high-elevation agriculture in the central Tien Shan during the mid-third millennium B.C.E. PLOS ONE 15: e0229372. doi: 10.1371/journal.pone.0229372.

Motuzaite Matuzeviciute, G., B. Mir-Makhamad, and R. N. Spengler. 2021a. Interpreting diachronic size variation in prehistoric Central Asian cereal grains. Frontiers in Ecology and Evolution 9:1-15. doi: https://doi.org/10.3389/fevo.2021.633634.

Motuzaite Matuzeviciute, G., B. Mir-Makhamad, and K. Tabaldiev. 2021b. First comprehensive archaeobotanical analysis of prehistoric agriculture in Kyrgyzstan. Vegetation History and Archaeobotany 30:743-758. doi: https://doi.org/10.1007/ s00334-021-00827-0.

Motuzaite Matuzeviciute, G., K.Tabaldiev, T. Hermes, E. Ananyevskaya, M. Grikpedis, E. Luneau, I. Merkyte, and L. Rouse. 2019. High-altitude agropastoralism in the Kyrgyz Tien Shan: New excavations of the chap farmstead (1065-825 cal bc). Journal of Field Archaeology 45(1):29-45.

Mukhamedzhanov, A., T. Adylov, D. Mirzaakhmedov, and G. Semenov. 1988. Городище Пайкенд. К проблеме изучения средневекового города Средней Азии (Paykend settlement. On the problem of studying the medieval city of Central Asia). Tashkent, Uzbekistan: Fan.

Narshakhi. 943. Tarikh-i-Bukhara (The history of Bukhara)(translated by Rishard Frye in 1954). Cambridge, Massachusetts: Crimson Printing Company.

Naymark, A. 1992. Географический фактор в истории Пайкенда (Geographic factor in the history of Paykend). In: Социально-пространственные структуры в стадиальной характеристике культурно- исторического процесса. Тезисы докладов конференции, ed., V. P. Guyaev, 175177 Moscow: Institute of Archeology RAS.

Neef, R., R. T. J. Cappers, R. M. Bekker, L. Boulos, M. Dinies, Z. F. Ertuğ, N. Keller, M. Lahitte, G. J. Meulenbeld, and Y. P. Zhu. 2012. Digital atlas of economic plants in archaeology. Groningen, the Netherlands: Barkhuis \& Groningen University Library.

Nekrasova, E. and A. Torgoev. 2016. Бухара и Бухарский Оазис в Эпоху Ибн-Фадлана (Bukhara and Bukhara Oasis in the Age of Ibn Fadlan). In: Путешествие Ибн-Фадлана: Волжский Путь От Багдада До Булгара (Ibm-Fadlan's Journey: Volga route from Baghdad to Bulghar), eds., I. R. Akhmedov and A. I. Torgoev, 138-148. Moscow: Mardjani Publishing House.

Omel'chenko, A. V. 2013. Цитадель Пайкенда в III-V вв. (Paykend citadel in III-V centuries C.E.). Российская археология 2(1):105-118. . 2019. New excavations in the Paikend CitySite-The Sogdian pottery assemblage of the Hellenistic period. In: Urban cultures of Central Asia from the Bronze Age to the Karakhanids: Learnings and conclusions from new archaeological 
investigations and discoveries. Proceedings of the First International Congress on Central Asian Archaeology held at the University of Bern, 4-6 February 2016, eds., C. Baumer and M. Novák, 203-226. Wiesbaden, Germany: Harrassowitz.

Paris, H. S., Z. Amar, and E. Lev. 2012. Medieval emergence of sweet melons, Cucumis melo (Cucurbitaceae). Annals of Botany 110(1):23-33.

Paul, J. 2001. Nouvelles Pistes Pour La Recherche Sur l'histoire de l'Asie Centrale à l'époque Karakhanide (Xe-Début XIIIe Siècle). Cahiers d'Asie Centrale 9(1):13-34.

Pokharia, A. K., J. S. Kharakwal, and A. Srivastava. 2014. Archaeobotanical evidence of millets in the Indian subcontinent with some observations on their role in the Indus civilization. Journal of Archaeological Science 42: 442-455. doi: https:// doi.org/10.1016/j.jas.2013.11.029.

Pollegioni, P., K. Woeste, F. Chiocchini, S. Del Lungo, M. Ciolfi, I. Olimpieri, V. Tortolano, J. Clark, G. E. Hemery, S. Mapelli, and M. E. Malvolti. 2017. Rethinking the history of common walnut (Juglans regia L.) in Europe: Its origins and human interactions. PLOS ONE 12(3): e0172541.

Pollegioni, P., K. E. Woeste, F. Chiocchini, S. Del Lungo, I. Olimpieri, V. Tortolano, J. Clark, G. E. Hemery, S. Mapelli, and M. E. Malvolti. 2015. Ancient humans influenced the current spatial genetic structure of common walnut populations in Asia. PLOS ONE 10(9):e0135980.

Pollegioni, P., K. E. Woeste, F. Chiocchini, I. Olimpieri, V. Tortolano, J. Clark, G. E. Hemery, S. Mapelli, and M. E. Malvolti. 2014. Landscape genetics of Persian walnut (Juglans regia L.) across its Asian range. Tree Genetics \& Genomes 10:1027-1043. doi: https://doi.org/10.1007/s11295-014-0740-2.

Pritsak, O. 1951. Von den Karluk zu den Karachaniden. Zeitschrift der Deutschen Morgenländischen Gesellschaft 101(26):270-300.

- 1953. Die Karachaniden. Der Islam 31(1):17-68.

Rante, R. and D. Mirzaakhmedov. 2019. The Oasis of Bukhara, Volume 1: Population, depopulation and settlement evolution. Leiden, the Netherlands: Brill.

Reimer, P. J., W. E. N. Austin, E. Bard, A. Bayliss, P. G. Blackwell, C. Bronk Ramsey, M. Butzin, H. Cheng, R. L. Edwards, M. Friedrich, P. M. Grootes, T. P. Guilderson, I. Hajdas, T. J. Heaton, A. G. Hogg, K. A. Hughen, B. Kromer, S. W. Manning, R. Muscheler, J. G. Palmer, C. Pearson, J. van der Plicht, R. W. Reimer, D. A. Richards, E. M. Scott, J. R. Southon, C. S. M. Turney, L. Wacker, F. Adolphi, U. Büntgen, M. Capano, S. M. Fahrni, A. Fogtmann-Schulz, R. Friedrich, P. Köhler, S. Kudsk, F. Miyake, J. Olsen, F. Reinig, M. Sakamoto, A. Sookdeo, and S. Talamo. 2020. The IntCal20 northern hemisphere radiocarbon age calibration curve ( $0-55$ cal kBP). Radiocarbon 62(4):725-757.

Renfrew, J. M. 1973. Paleoethnobotany: The prehistoric food plants of the Near East and Europe. New York: Columbia University Press.

Robbeets, M. and A. Savelyev, eds. 2017. Language dispersal beyond farming. Amsterdam and Philadelphia: John Benjamins Publishing Company.

Semenov, G. 2002. Согдийский город V-XI вв., формирование плана: По материаламПайкенда в Бухарском оазисе и Ак-Бешима в Семиречье (Sogdian city of the 5 th -11 th centuries, plan formation: Based on the materials of Paykend in the Bukhara Oasis and Ak-Beshim in Semirechye). Ph.D. Dissertation. Saint Petersburg, Russia: The State Hermitage Museum.

Shapiro Ledley, T., J. Rooney-Varga, and F. Niepold. 2017. Addressing climate change through education. Online https://oxfordre.com/environmentalsc ience/view/10.1093/acrefore/9780199389414.001. 0001/acrefore-9780199389414-e-56.

Sherratt, A. 1999. Cash-crops before cash: Organic consumables and trade. In: The prehistory of food: Appetites for change, eds., C. Gosden and J. G. Hather, 13-34. London: Routledge.

Smith, A., T. Bagoyan, I. Gabrielyan, R. Pinhasi, and B. Gasparyan. 2014. Late Chalcolithic and medieval archaeobotanical remains from Areni-1 (Birds' Cave), Armenia. In: Stone Age of Armenia, eds., B. Gasparyan and M. Arimura, 233-260. Kanazawa, Japan: Center for Cultural Resource Studies.

Spengler, R. N. 2019a. Fruit from the sands: The Silk Road origins of the foods we eat. Oakland, California: University of California Press.

- 2019b. Origins of the apple: The role of megafaunal mutualism in the domestication of Malus and Rosaceous trees. Frontiers in Plant Science 10:1-18. doi: https://doi.org/10.3389/fpls.2019. 00617.

_ 2019c. Dung burning in the archaeobotanical record of West Asia: Where are we now? Vegetation History and Archaeobotany 28:215-227. doi: https://doi.org/10.1007/s00334-018-0669-8.

Spengler, R. N. and G. Willcox. 2013. Archaeobotanical results from Sarazm, Tajikistan, an Early Bronze Age settlement on the edge: Agriculture and exchange. Environmental Archaeology 18(3):211-221.

Spengler, R. N., C. Chang, and P. A. Tourtellotte. 2013a. Agricultural production in the Central Asian mountains: Tuzusai, Kazakhstan (410-150 B.C.). Journal of Field Archaeology 38(1):68-85.

Spengler, R. N., M. D. Frachetti, and G. J. Fritz. 2013b. Ecotopes and herd foraging practices in the steppe/ mountain ecotone of Central Asia during the Bronze and Iron Ages. Journal of Ethnobiology 33(1):125-147. 
Spengler, R. N., F. Maksudov, E. Bullion, A. Merkle, T. Hermes, and M. Frachetti. 2018. Arboreal crops on the medieval Silk Road: Archaeobotanical studies at Tashbulak. PLoS ONE 13(9):1-16.

Spengler, R. N., N. F. Miller, R. Neef, P. A. Tourtellotte, and C. Chang. 2017. Linking agriculture and exchange to social developments of the Central Asian Iron Age. Journal of Anthropological Archaeology 48:295-308. doi: https://doi.org/10. 1016/j.jaa.2017.09.002.

Stark, S., K. Mirzaakhmedov, F. Kidd, S. Krivonogov, and S. Mirzaakhmedov. 2017. Отчет УзбекскоАмериканской Экспедиции в Бухаре (УзАмЭБ) 2016 Года (Report of the Uzbek-American Expedition in Bukhara (UzAmeB) 2016). Samarkand, Uzbekistan: ASRU.

Starr, S. F. 2013. Lost enlightenment: Central Asia's golden age from the Arab conquest to Tamerlane. Princeton, New Jersey: Princeton University Press.

Stevens, C. J., C. Murphy, R. Roberts, L. Lucas, F. Silva, and D. Q. Fuller. 2016. Between China and South Asia: A Middle Asian corridor of crop dispersal and agricultural innovation in the Bronze Age. The Holocene 26(10):1541-1555.

Tang, L., H. Lu, J. Song, S. Wangdue, X. Chen, Z. Zhang, X. Liu, N. Boivin, and R. N. Spengler. 2021. The transition to a barley-dominant cultivation system in Tibet: First millennium B.C.E. archaeobotanical evidence from Bangga. Journal of Anthropological Archaeology 61:101242. doi: 10.1016/j. jaa.2020.101242.

Umnyakov, I. 1927. Рабат-и Малик (Rabat- i - Malik). In: B. В. Бартольду туркестанские друзья, ученики и почитатели (To Barthold V.V. Turkestan friends, students and admirers), eds., A. E. Schmidt and E. K. Boettger, 179-192. Tashkent, Uzbekistan: KazGiZ.

Vavilov, N. I. 1950. The phytogeographic basis of plant breeding. The origin, variation, immunity and breeding of cultivated plants. Chronica Botanica 13(1):1-6.
Wang, L., J. Yang, T. Liang, J. Yang, C. J. Grassa, and H. Jiang. 2020. Seeds of melon (Cucumis melo L., Cucurbitaceae) discovered in the principal tomb (M1) of Haihun Marquis (59 B.C.E.) in Nanchang, China. Archaeological and Anthropological Sciences 12:1-14. doi: https://doi.org/10.1007/ s12520-020-01147-6.

Weisskopf, A. and D. Q. Fuller. 2014. Apricot: Origins and development. In: Encyclopedia of Global Archaeology, ed., K. Smith, 294-296. New York: Springer New York.

Whitfield, S. 2019. Silk roads: Peoples, cultures, landscapes. Berkeley, California: University of California Press.

Willcox, G. 1991a. Carbonised plant remains from Shortughai. In: New light on early farming: recent developments in palaeoethnobotany, ed., J. Renfrew, 139-154. Edinburgh, Scotland: Edinburgh University Press.

1991b. Exploitation des espèces ligneuses au Proche-Orient: Données anthracologiques. Paléorient 17(2):117-126.

Willcox, G. H. 1974. A history of deforestation as indicated by charcoal analysis of four sites in eastern Anatolia. Anatolian Studies 24:117-133. doi: https://doi.org/10.2307/3642603.

Wu, X., N. F. Miller and P. Crabtree. 2015. Agro-Pastoral strategies and food production on the Achaemenid Frontier in Central Asia: A case study of Kyzyltepa in Southern Uzbekistan. Iran 53(1):93-117.

Zeven, A. C. and J. M. J. De Wet. 1982. Dictionary of cultivated plants and their regions of diversity: Excluding most ornamentals, forest trees and lower plants. Wageningen, the Netherlands: Centre for Agricultural Publicating and Documentation.

Zohary, D., M. Hopf, and E. Weiss. 2012. Domestication of plants in the Old World: The origin and spread of domesticated plants in Southwest Asia, Europe, and the Mediterranean Basin. Oxford, United Kingdom: Oxford University Press. 